\title{
Enhanced economic feasibility of excess sludge treatment: acid fermentation with biogas production
}

\author{
Mo-Kwon Lee ${ }^{1,2}$, Yeo-Myeong Yun² and Dong-Hoon Kim
}

\begin{abstract}
The excess sludge (ES) generated from wastewater treatment plants entails high expenditure for its treatment and disposal. In this study, firstly, the influence of mild-thermal (70 and $90^{\circ} \mathrm{C}$ ) and alkali-(pH 10 and 11) pretreatment methods on solubilization and acid generation from ES was investigated. The experimental results showed that the solubilization (SCOD/TCOD) increased as pretreatment intensity increased $\left(70^{\circ} \mathrm{C}<90^{\circ} \mathrm{C}<\mathrm{pH} 10<\mathrm{pH} 11\right)$. However, organic acids generation was not consistent with the increased solubilization $\left(\mathrm{pH} 11<70^{\circ} \mathrm{C}<90^{\circ} \mathrm{C}<\mathrm{pH} 10\right)$. As a result of microbial analysis through next generation sequencing (NGS), it was observed that microbial community structure was greatly varied depending on the pretreatment methods. Bacteroidetes (70.8\%), and Firmicutes (58.1\%) were found to be dominant at thermal conditions of $90^{\circ} \mathrm{C}$ and $\mathrm{pH} 10$. Furthermore, the solid residue after acids generation was subjected to anaerobic digestion (AD) for $\mathrm{CH}_{4}$ production. The economic assessment showed that the thermal pretreatment at $90^{\circ} \mathrm{C}$ followed by acid recovery and AD process enhanced the net profit of the treatment process with a positive gain of $2.53 \mathrm{USD} /$ ton of sludge. Meanwhile, the alkali-pretreatment at pH 11 showed a negative value of -2.0 USD/ton of sludge.
\end{abstract}

Keywords: Anaerobic digestion, Excess sludge, Economic assessment, Organic acids, Solubilization

\section{Introduction}

The handling of excess sludge (ES) in municipal wastewater treatment plant is a huge economic burden, accounting for $30-40 \%$ of the total capital cost and $50 \%$ of plant operation cost $[1,2]$. The reduction of sludge volume via anaerobic digestion (AD) is thus gaining a lot of attention, which converts organic wastes to $\mathrm{CH}_{4}$-rich biogas, inactivates pathogens, and improves dewaterability of the sludge cake [3]. However, the digestion efficiency is often hindered by the low hydrolysis efficiency of ES. The main component of ES is microbial cells and their cell walls containing glycan strands, which cause resistance to biodegradation $[4,5]$. To improve the digestion efficiency, various disintegration methods such as physical, chemical, thermal, alkali, microwave, and biological treatment or a combination of any two of these methods have been applied [6-12]. High-strength

\footnotetext{
* Correspondence: dhkim77@inha.ac.kr

${ }^{1}$ Department of Civil Engineering, Inha University, 100 Inharo, Michuhol-gu, Incheon 22212, Republic of Korea

Full list of author information is available at the end of the article
}

of pretreatment warrants increased solubilization with enhanced digestion efficiency, but it could add an economic burden $[13,14]$.

On the other hand, valuable organic acids such as acetate, lactate, butyrate, and propionate can also be obtained during AD. They can be utilized as a substitute for methanol $(0.45 \mathrm{USD} / \mathrm{kg})$ that is commonly used as an extra carbon source in the denitrification process [15-17]. Organic acids are generated in the intermediate-stage of $\mathrm{AD}$, which are finally converted to $\mathrm{CH}_{4}$ unless methanogenesis is inhibited. Heat- and alkali-shock have often been used to inactivate methanogens in the seeding sources and ES. Yuan et al. [18] have reported that organic acids production from the ES was considerably improved under alkali condition $(\mathrm{pH} 10)$, and Xiao et al. [19] observed the 4.2 times higher organic acids production from heat-treated ES compared to raw sludge.

Without inoculum addition, ES can be self-fermented to organic acids under anaerobic condition. The indigenous bacteria such as Clostridium, Anaerobranca, 
Tissierella, and Paludibacter can degrade carbonaceous compounds in the sludge to various acids [20,21]. This could be a simple process in terms of not requiring inoculum preparation and practical mean to conduct fermentation during the storage period. However, the organic acids yield is limited to less than 5\%, and even the methanogenic activity that consuming produced acids has often been observed after a few days [19]. Therefore, pretreatment is essential, which can both increase organic acids generation and inhibit the methanogenic consumption. After producing acids, the remained solid residue obtained via liquid/solid separation can also be further digested to reduce sludge volume and gain $\mathrm{CH}_{4}$.

In the present study, three experimental scenarios were designed: 1). biogas production from raw ES by AD (S1), 2). biogas production from pretreated ES by $A D$ (S2), and 3). organic acids generation from pretreated ES and biogas production from the solid residue (S3) (Fig. 1). Since a huge amount of energy consumption in the pretreatment would offset the beneficial effect, the pretreatment was applied in a mild range: the temperature at $70^{\circ} \mathrm{C}$ and $90^{\circ} \mathrm{C}$, and $\mathrm{pH}$ at 10 and 11 . In addition, the economic assessment was conducted using the experimental results. To our knowledge, this is the first report assessing the economic aspect of sludge pretreatments for $\mathrm{AD}$ with organic acids generation.

\section{Results and discussion}

\section{Effects of pretreatment}

Soluble chemical oxygen demand (SCOD) is considered as the important factor to assess the bioavailability of the organic contents of the sludge [5]. As shown in Fig. 2, the soluble ratio of total chemical oxygen demand (TCOD) (SCOD/TCOD) increased after pretreatment. The highest solubilization ratio of
33.6\% was observed from the alkali-pretreatment at $\mathrm{pH} 11$. This value was similar to the report by Kavitha et al. [22], where $35 \%$ of sludge solubilization was observed under thermo-alkali-sonic pretreatment. In this study, the alkali pretreatment at $\mathrm{pH} 11$ showed a maximum SCOD release of $8066 \mathrm{mg}$ COD/L. On the other hand, alkali-pretreatment at $\mathrm{pH} 10$ showed the moderate solubilization of $24.5 \%$ with a SCOD release of $5885 \mathrm{mg} \mathrm{COD} / \mathrm{L}$.

During the thermal pretreatment, which was operated for $30 \mathrm{~min}$, an improvement in the ES solubilization ranging from 17.1 to $23.3 \%$ was observed. Similarly, Zhen et al. [23] reported that thermal pretreatment not only improved the sludge disintegration but also assisted in the removal of pathogen/odor. Such results are promising because of being obtained at a moderate temperature (70 and $90^{\circ} \mathrm{C}$ ). Contrary, most of the studies employed for the sludge disintegration via thermal pretreatment were studied in a higher temperature range of 121 to $210^{\circ} \mathrm{C}$, at which a limited impact of temperature on the sludge solubilization was harvested [24]. Moreover, these high temperatures led to the reduced sludge dewaterability with the generation of toxic substrates that hindered the sludge biodegradability [25]. Such drawbacks are overcome while applying moderate temperature-based pretreatment, which has additional cost advantages. Nevertheless, the latter requires more research in order to address the challenge of duration requested for effective solubilization.

The pretreated ES was subjected to acidogenic self-fermentation with an emphasis on organic acids generation and the results are shown in Fig. 3. It was found that organic acids' concentration decreased from 4.1 to $3.2 \mathrm{~g} \mathrm{COD} / \mathrm{L}$ by raising pretreatment $\mathrm{pH}$ from 10 to 11 . Meanwhile, a contrary behavior was observed in the case of temperature increase from 70

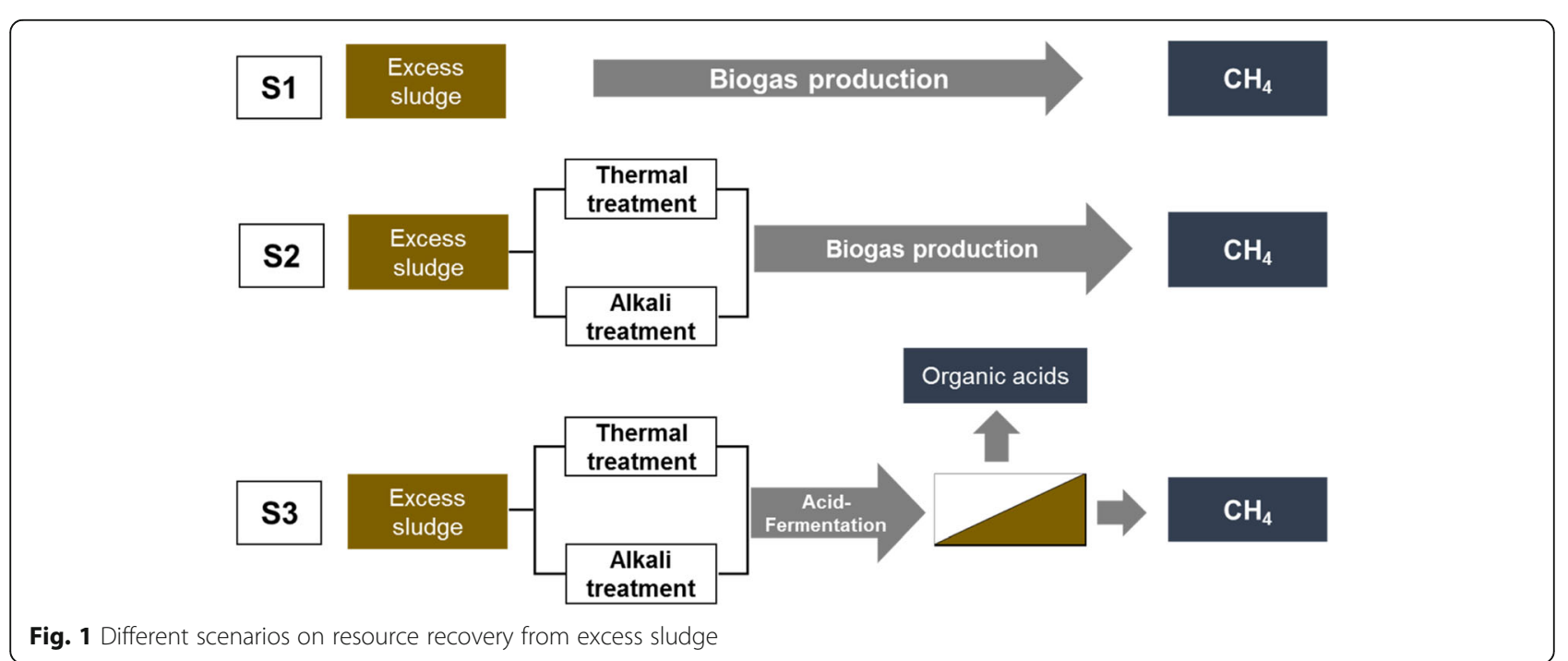




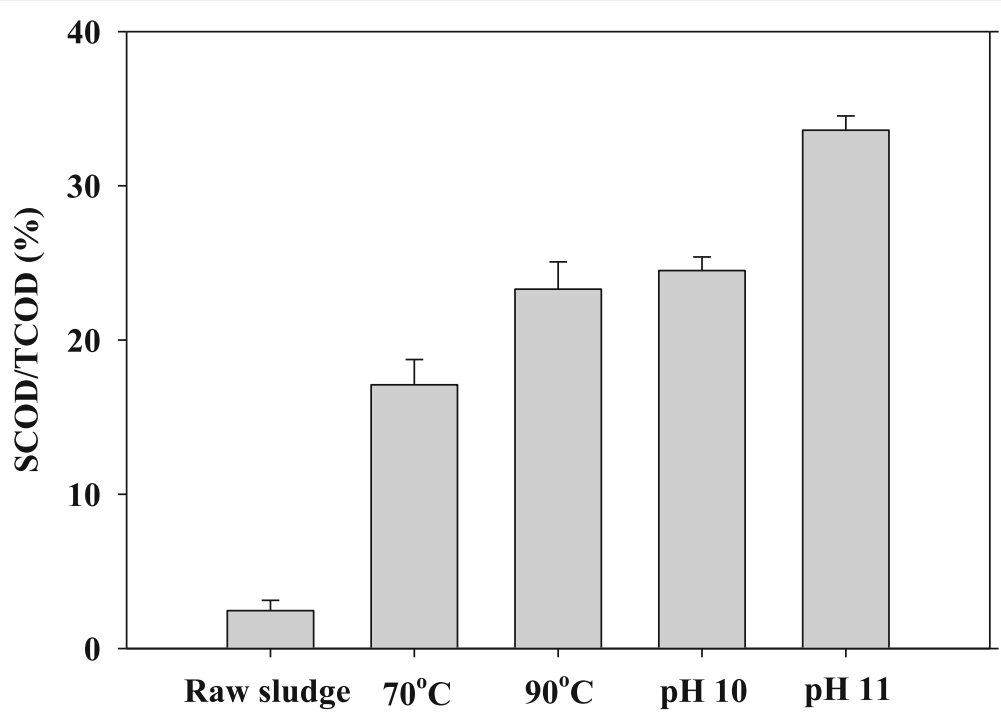

Fig. 2 The solubilization of excess sludge after pretreatment

to $90^{\circ} \mathrm{C}$, while acids' concentration was found to be augmented from 3.3 to $3.8 \mathrm{~g} \mathrm{COD} / \mathrm{L}$. The maximum organic acids accumulation value was observed at $\mathrm{pH}$ 10. The main portions of produced organic acids were acetate $(61-78 \%)$, propionate $(8-11 \%)$, and butyrate (17-30\%), which are known as the main byproducts of acidogenic bacteria [26-28]. The changes in the bacterial communities during acidogenic fermentation affected the distribution of the organic acids accumulation and were summarized in the following section.

$\mathrm{pH}$ has a major influence on the organic acids production and their optimal range between 5.0 to 6.5 was essential to improve the organic acids production. However, in this study, no initial $\mathrm{pH}$ adjustment was made during the self-acidogenic fermentation in order to reduce the chemical costs and assess the practical

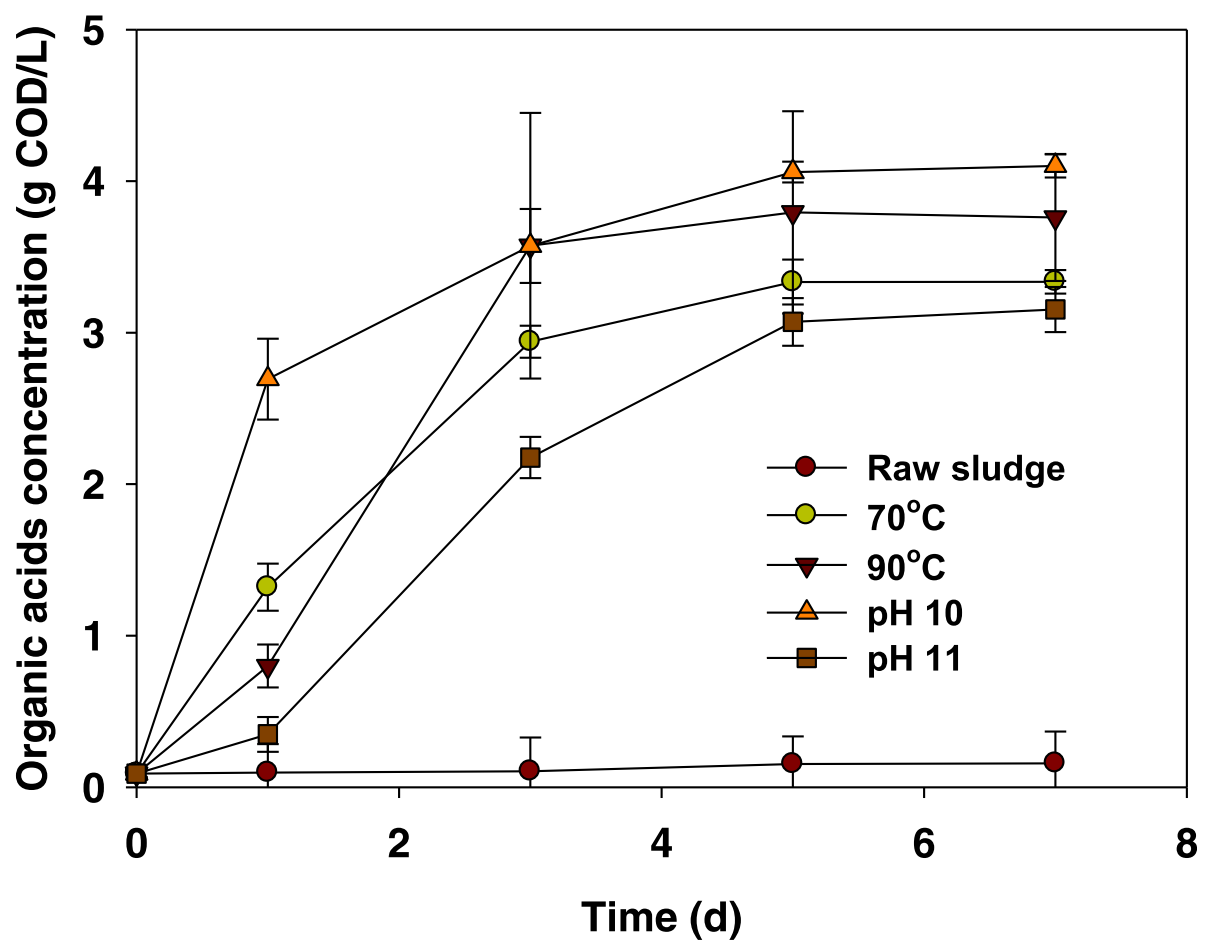

Fig. 3 Organic acids production profiles of pretreated sludges 
applicability of the process. $\mathrm{CH}_{4}$ production was detected after day 7 of the self-acidogenic fermentation, which inferred that long acclimatization time was required for the reactivation of methanogens after the heat and alkali-shock pretreatment [22]. Although $\mathrm{pH} 11$ was effective in sludge solubilization, the acid accumulation was greatly affected than other conditions [27]. It seemed that high-alkali condition inhibits the acid-producing bacteria, resulting in the less production of organic acids [28]. After fermentation of $7 \mathrm{~d}$, the $\mathrm{pH}$ value was observed in the range of 6.3 to 7.5 at the thermal and alkali conditions of $\mathrm{pH} 10$. However, in case of $\mathrm{pH} 11$, the $\mathrm{pH}$ value was slightly high over 8.9.

\section{Microbial community}

The microbial community analysis was performed via 454 pyrosequencing method to monitor the bacterial changes in the acidogenic fermentation of the pretreated ES. Figure 4 shows the microbial abundance at the phylum level distribution at the pretreated samples. The structure of the microbial community varied with pretreatment conditions. Most of the bacteria were classified as five major phyla (Proteobacteria, Bacteroidetes, Firmicutes, Actinobacteria, and Fusobacteria). Proteobacteria and Bacteroidetes were the major abundant in the control experiment (Raw-ES) and $\mathrm{pH} 11$, which showed the lowest organic acids production. At $70^{\circ} \mathrm{C}, 90^{\circ} \mathrm{C}$ and $\mathrm{pH} 10$ conditions, the dominance of Firmicutes was significantly increased to $13.9,24.2$, and $58.1 \%$, respectively. The selective enrichment of the acid-producing
Firmicutes populations after the pretreatment step coincided with the observed increased proportion of the organic acids production. Also, as the thermal pretreatment intensity increased from $70{ }^{\circ} \mathrm{C}$ to $90^{\circ} \mathrm{C}$, Bacteroidetes was enriched to 30.8 and $70.8 \%$, whereas it was decreased to $7-8 \%$ in the alkali pretreatment.

In order to further confirm the bacterial community, the genus level analysis was performed after removing the genus with low relative abundance $(<1 \%)$ (Table 1 ). Parabacteroides (19.5\%) and Clostridium (6.3\%), which are known as acetic acid producing bacteria and hydrogen producers, were slightly enriched at low temperature $\left(70{ }^{\circ} \mathrm{C}\right)$ pretreatment and significantly increased at $90^{\circ} \mathrm{C}$ to a value of 70.1 and $18.9 \%$, respectively $[29,30]$. This shows that variation within the thermal $\left(70\right.$ and $\left.90{ }^{\circ} \mathrm{C}\right)$ pretreatment affected the microbial groups and the sludge disintegration.

At the alkali-pretreatment condition of $\mathrm{pH} 10$, the Tissierella and Proteinclasticum were the dominant bacterial group, accounting for 32.8 and $20.4 \%$ of the total number of microbial community. These genera seemed to play a major role in organic acids production. According to previous research, Tissierella was also involved in acetic acid and butyric acid production and Proteinclasticum was known to be involved in the hydrolysis of proteins and the production of acetic acid and butyric acid $[30,31]$. At pH 11, the Dechloromonas was the major population occupying $41.3 \%$ while Proteinclasticum was found to be $2.0 \%$. These results inferred that understanding microbial dynamics is essential for

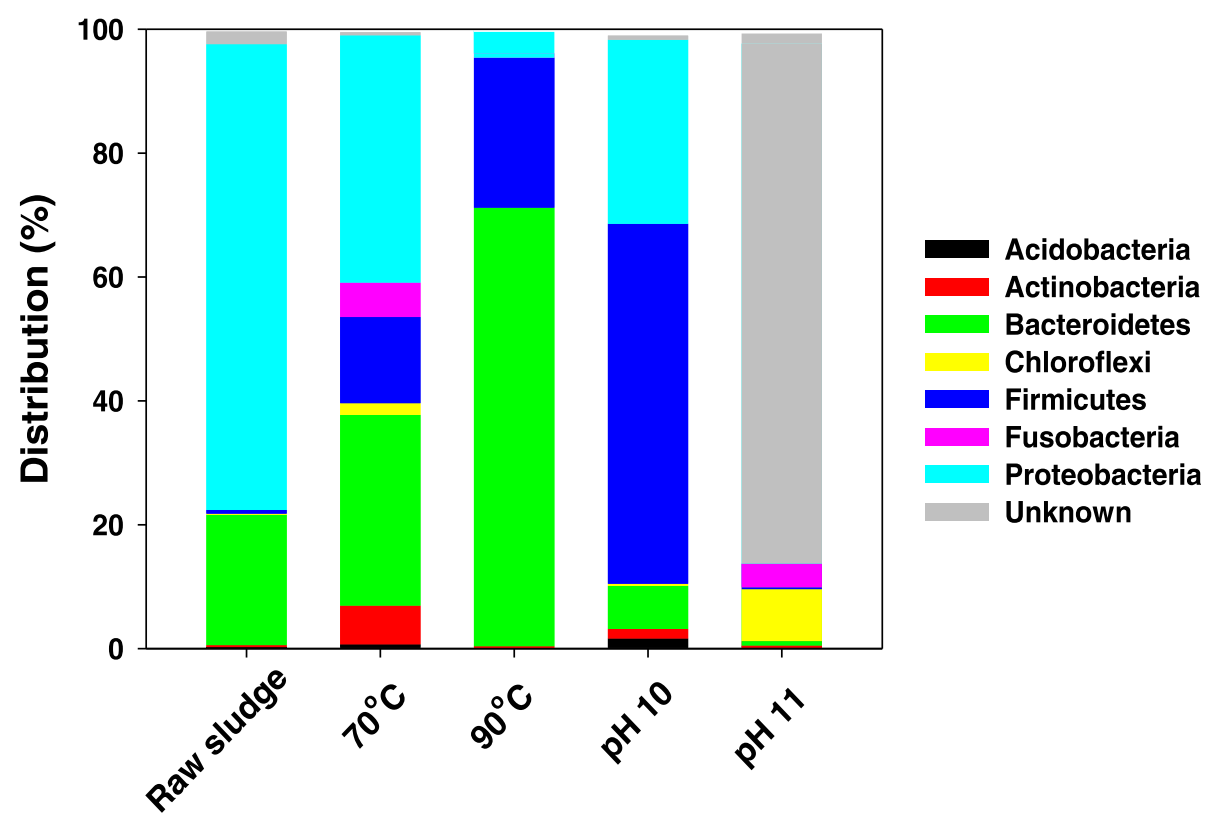

Fig. 4 Microbial community distribution at phylum level 
Table 1 Phylogenetic classification of the dominant sequences (relative abundance $>1 \%$ at genus level) in the acidified broth of pretreated and raw ES

\begin{tabular}{|c|c|c|c|c|c|c|}
\hline Phylum & Genus & Raw sludge & Thermal $\left(70^{\circ} \mathrm{C}\right)$ & Thermal $\left(90^{\circ} \mathrm{C}\right)$ & Alkali (pH 10) & Alkali (pH 11) \\
\hline Proteobacteria & Dechloromonas & 51.0 & 4.7 & 1.2 & 4.5 & 41.3 \\
\hline Bacteroidetes & Flavisolibacter & 15.0 & 4.6 & 0.0 & 6.8 & 6.2 \\
\hline Proteobacteria & Methylotenera & 7.0 & 0.8 & 0.1 & 0.0 & 4.1 \\
\hline Bacteroidetes & Parabacteroides & 0.0 & 19.5 & 70.1 & 0.0 & 0.0 \\
\hline Proteobacteria & Thermomonas & 1.4 & 8.1 & 0.2 & 9.9 & 1.1 \\
\hline Firmicutes & Clostridium & 0.0 & 6.3 & 18.9 & 1.9 & 0.0 \\
\hline Actinobacteria & Tetrasphaera & 0.2 & 5.9 & 0.3 & 0.8 & 0.5 \\
\hline Firmicutes & Tissierella & 0.0 & 0.0 & 0.0 & 32.8 & 0.0 \\
\hline Firmicutes & Proteinclasticum & 0.2 & 0.0 & 0.1 & 20.4 & 2.0 \\
\hline Proteobacteria & Azospira & 1.7 & 9.0 & 0.3 & 1.5 & 18.8 \\
\hline
\end{tabular}

optimizing the suitable pretreatment conditions for sludge disintegration and subsequent utilization for bioenergy production.

\section{Biogas production and COD mass flow}

Similar to the organics release, the biogas content and AD performances were varied among the tested conditions. The highest biogas yield of $39.8 \%$ was achieved at the $\mathrm{pH}$ of 10 , followed by $90{ }^{\circ} \mathrm{C}(39.5 \%), \mathrm{pH} 11$ (37.8\%), $70{ }^{\circ} \mathrm{C}(34.0 \%)$, and raw sludge (22\%), respectively (Fig. 5). In case of $\mathrm{S} 3$ (where the biodegradable fraction of sludge was removed by centrifugation), the biogas yield ranged 18.0 to $25.0 \%$. The solubilization at $\mathrm{pH} 11$ was 1.4 -fold higher than that of $\mathrm{pH} 10$, but biogas production was lower. These results showed that the solubilization ratio increased with the pretreatment strength increase, but biogas yield was inconsistent with solubilization [5, 32]. In this regard, Penaud et al. (1999) reported that when sludge was pretreated with excess alkali dosage, biodegradability can be decreased caused by the formation of refractory compounds due to the Maillard reaction [33]. Unlike the alkali pretreatment, no inhibitory effect such as Maillard reaction was found in thermal pretreatment at $90^{\circ} \mathrm{C}$, which corresponds to the low temperature range [8].

Considering the biogas yield achieved, and the volume of the solid/liquid fraction after centrifugation, the COD mass flow at different scenarios is depicted in Fig. 6. The

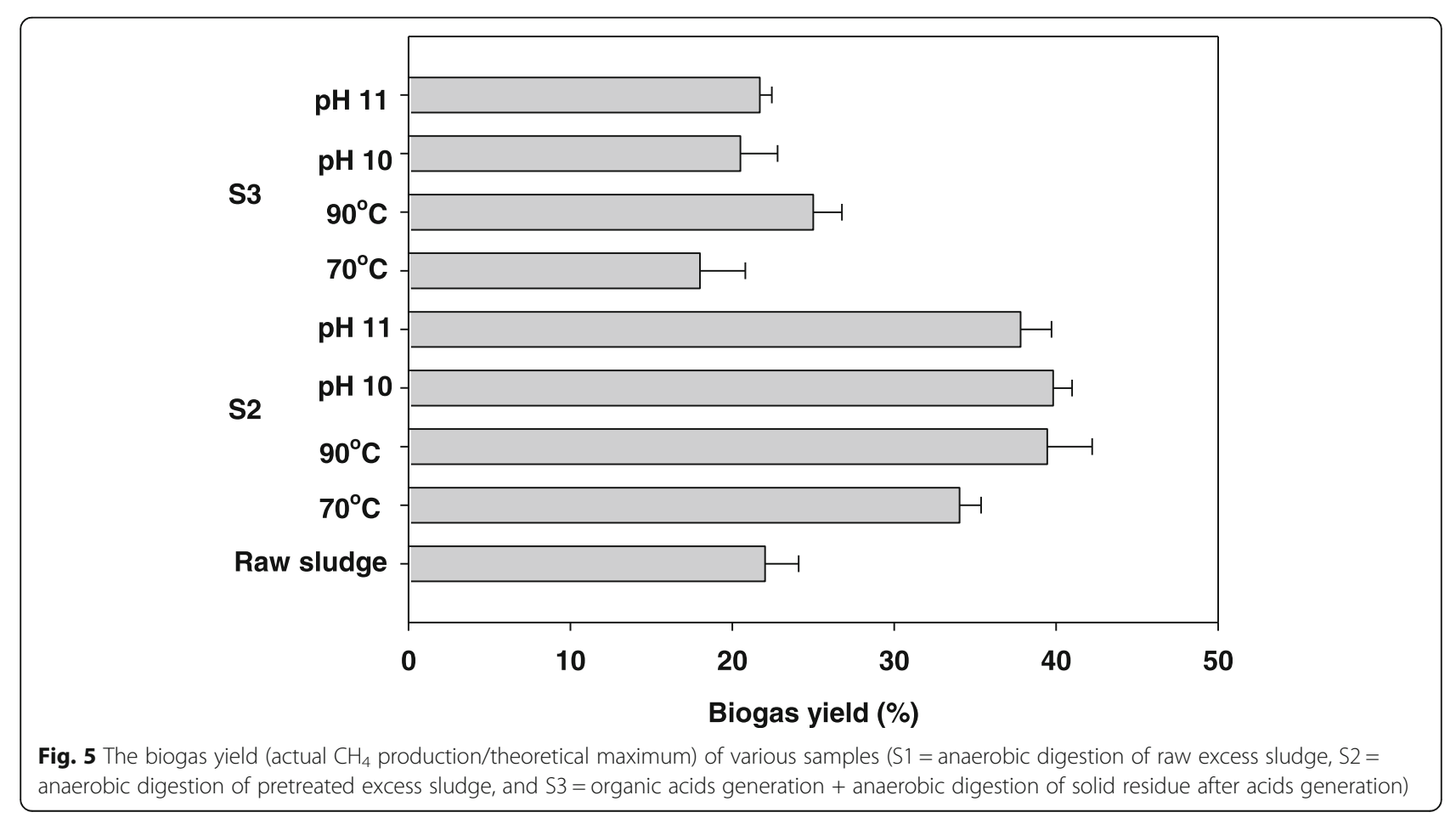




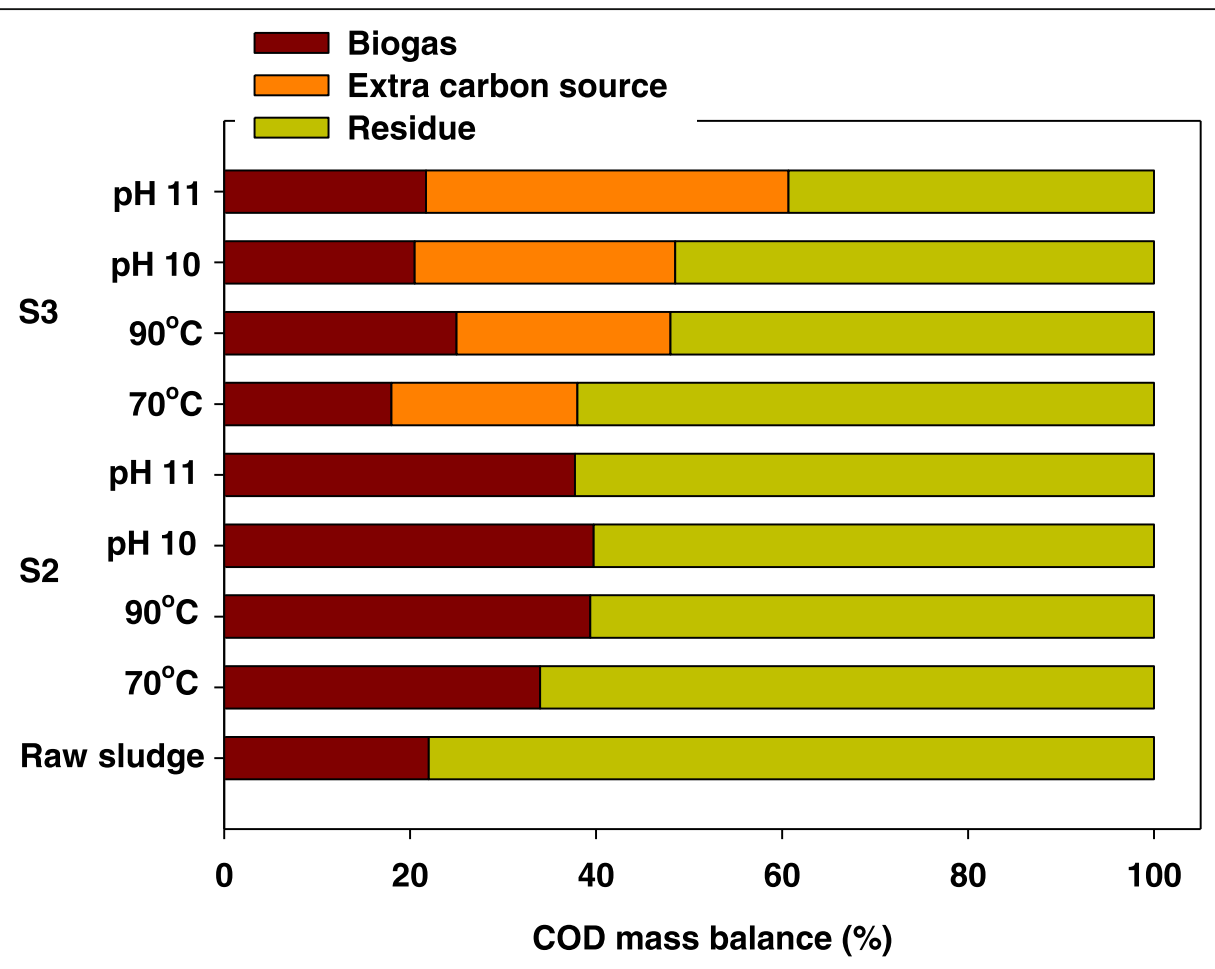

Fig. 6 The COD mass flow at different scenarios

separation efficiency on a volume basis (liquid:solid) were $81: 19,82: 18,81: 19$, and $84: 16$ at $70^{\circ} \mathrm{C}, 90^{\circ} \mathrm{C}, \mathrm{pH}$ 10 , and $\mathrm{pH} 11$, respectively. The percentage of COD on liquid/solid fraction were 20/80, 23/77, 28/72, and 39/ 61 , at $70^{\circ} \mathrm{C}, 90^{\circ} \mathrm{C}, \mathrm{pH} 10$, and $\mathrm{pH} 11$, respectively. The total COD included biogas production, extra carbon source, and residues. In the case of S3, the COD from the biogas was lower than S2, but the COD from the external carbon source increased with the pretreatment strength, and consequently, the amount of available COD was higher in S3. At pH 11, available COD of S3 was $61 \%$ but at $\mathrm{S} 2$ it was about $38 \%$. However, it is difficult to evaluate without comparing cost and benefits. Therefore, the economic assessment was conducted focused on cost and benefit in the next section.

\section{Economic assessment}

The cost-benefit analysis of the sludge treatment was considered by calculating the energy returns and input required for handling 1 ton of sludge, and the results are shown in Fig. 7. The energy analysis was performed by comparing the energy obtained in the form of $\mathrm{CH}_{4}$ with the energy used for sludge pretreatment and digestion process. The amount of $\mathrm{CH}_{4}$ that can be obtained from 1 ton of raw sludge and pretreated sludge at $70^{\circ} \mathrm{C}, 90^{\circ}$ $\mathrm{C}, \mathrm{pH} 10$, and $\mathrm{pH} 11$ were $2.85,3.31,3.34$, and $3.17 \mathrm{~m}^{3}$, respectively, corresponding to an electrical energy of $18.4,28.4,32.9,33.2$, and $31.5 \mathrm{kWh}$, respectively $\left(1.0 \mathrm{~m}^{3}\right.$ of $\mathrm{CH}_{4}$ is equal to $35.85 \mathrm{MJ}$ based on low calorific value). The input energy used during digestion was assumed to be $14.7 \mathrm{kWh}$ [22]. For the thermalpretreatment at $70^{\circ} \mathrm{C}$ and $90^{\circ} \mathrm{C}, 22.5$ and $26.0 \mathrm{kWh}$ of additional energy is required, respectively.

Based on the achieved biogas yield and TCOD concentration of the raw sludge (S1), $3.96 \mathrm{~kg}$ of volatile solids (VS) reduction and $1.85 \mathrm{~m}^{3}$ of $\mathrm{CH}_{4}$ production per ton of sludge can be expected, corresponding to the economic benefit of $1.29 \mathrm{USD} / \mathrm{ton}$ of sludge [24]. The VS reduction was calculated considering that $1 \mathrm{~kg} \mathrm{VS}$ is equivalent to $1.33 \mathrm{~kg}$ COD [34].

In case of $\mathrm{S} 2$, the improvement of biodegradability resulted in the increase of $\mathrm{CH}_{4}$ production almost by double, when compared to S1. The thermalpretreatment resulted in the net profit of 2.0 and 2.3 USD/ton of sludge at 70 and $90^{\circ} \mathrm{C}$ respectively, whereas the chemical cost needed for alkali pretreatment was higher and resulted in a negative profit of -0.1 and -2.0 USD/ton of sludge at $\mathrm{pH} 10$ and 11, respectively. The cost for the chemical used in the pretreatment was calculated on the basis of $\mathrm{KOH}$ usage $(1.5$ and $2.4 \mathrm{~kg} \mathrm{KOH}$ at $\mathrm{pH} 10$ and 11, respectively) and its price of $2.0 \mathrm{USD} /$ $\mathrm{kg} \mathrm{KOH} \mathrm{[35].} \mathrm{Owing} \mathrm{to} \mathrm{the} \mathrm{high} \mathrm{pretreatment} \mathrm{cost,} \mathrm{the}$ alkali-pretreatment resulted in a negative gain of the process [36].

S3 seems to be an appropriate strategy for improving the economic feasibility from the process, due to their 


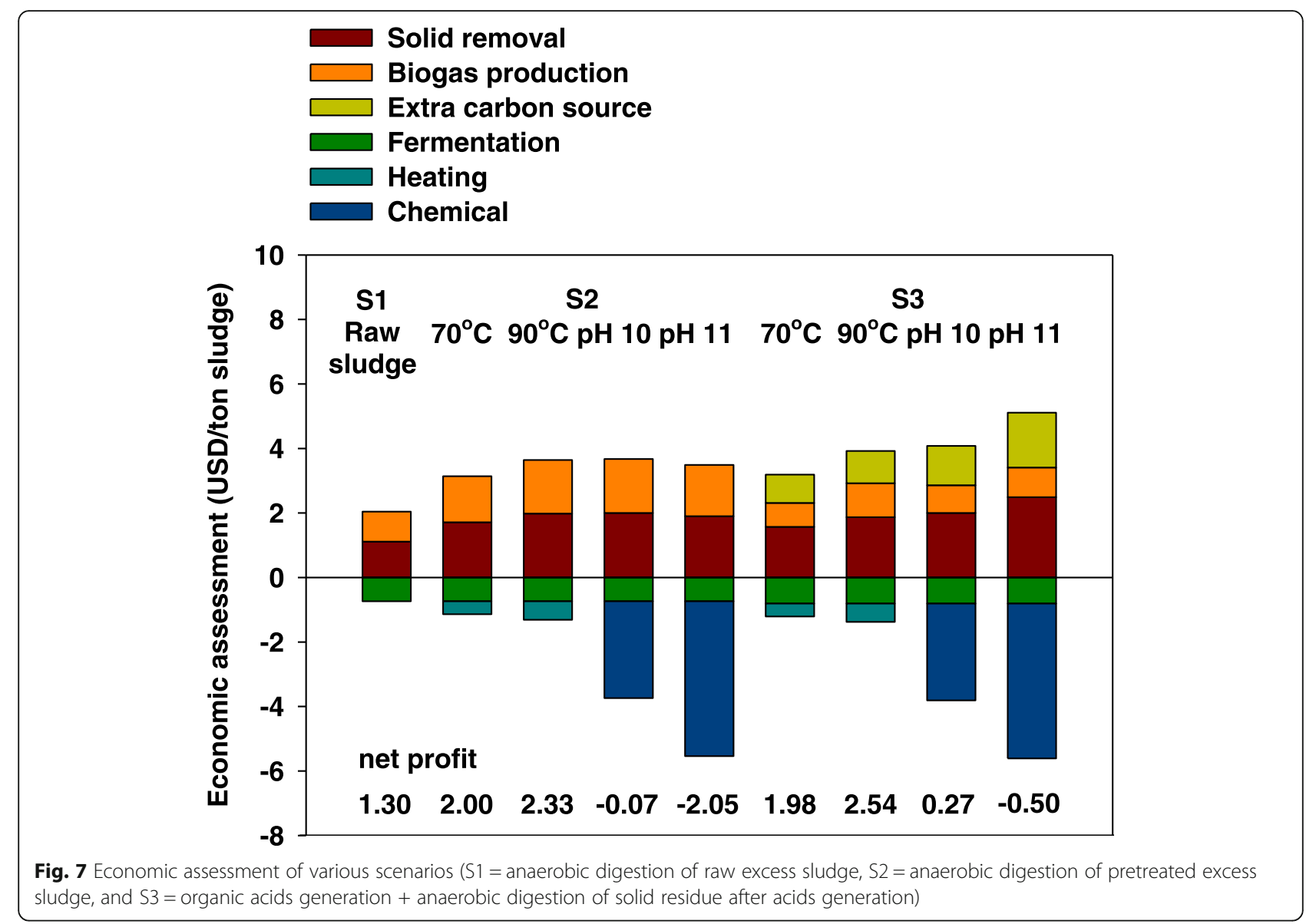

additional carbon energy source in the form of organic acids provided by the self-acidogenic fermentation. The additional carbon source obtained from pretreatment sludge of 1 ton at $70^{\circ} \mathrm{C}, 90^{\circ} \mathrm{C}, \mathrm{pH} 10$, and $\mathrm{pH} 11$ were $4.9,5.5,6.8$, and $9.4 \mathrm{~kg}$ COD, respectively. $60 \%$ of the obtained SCOD was available as a carbon source [37] and was calculated as a price corresponding to methanol equivalents $\left(1.5 \mathrm{~kg} \quad \mathrm{COD} / \mathrm{kg} \quad \mathrm{CH}_{3} \mathrm{OH}, \quad 0.45 \mathrm{USD} / \mathrm{kg}\right.$ $\left.\mathrm{CH}_{3} \mathrm{OH}\right)$. For example, the benefit of $\mathrm{S} 3$ pretreatment at $90{ }^{\circ} \mathrm{C}$ was approximately 1.0 USD, calculated as follows: $5.5 \mathrm{~kg} \mathrm{COD} / 1.5 \mathrm{~kg} \mathrm{COD} / \mathrm{kg} \mathrm{CH}{ }_{3} \mathrm{OH} \times 0.6 \times 0.45 \mathrm{USD} / \mathrm{kg}$ $\mathrm{CH}_{3} \mathrm{OH}$.

During the S3 conditions, the alkali-conditions of $\mathrm{pH}$ 10 and 11 slightly improved the economic benefit than the S2 conditions and showed a value of 0.3 and -0.5 at a pH of 10 and 11, respectively. The additional economic benefit by the self-acidogenic fermentation was offset by the high cost of alkali-pretreatment [38, 39]. Compared with alkali-pretreatment, the thermal pretreatment seems to be a feasible pretreatment option to enhance the economic benefits of the process. Based on the results obtained at the $\mathrm{S} 3$ condition, thermal pretreatment at $90{ }^{\circ} \mathrm{C}$ improved a net economic benefit of $2.53 \mathrm{USD} /$ ton of sludge.

\section{Conclusions}

This study evaluated the various scenarios of sludge disintegration based on AD technologies on economic cost and biodegradability. The outcomes showed that alkali pretreatment significantly improved the sludge solubilization and organic acids accumulation, whereas thermal treatment showed moderate sludge solubilization, but better energy recovery. The organic acids production from ES was 3.7 and $4.1 \mathrm{~g} \mathrm{COD} / \mathrm{L}$, which accounted for 15 and $17 \%$ of total COD at $90^{\circ}$ $\mathrm{C}$ and $\mathrm{pH} 10$, respectively. Thermal pretreatment at $90{ }^{\circ} \mathrm{C}$ showed an increased abundance of Bacteroidetes (70.8\%) and Firmicutes (24.2\%) with a biogas yield of $39.5 \%$. In terms of economic benefits, the thermal pretreatment at $90^{\circ} \mathrm{C}$, followed by acidogenic fermentation and $\mathrm{AD}$ process (S3) provided a net economic benefit of $2.53 \mathrm{USD} / \mathrm{ton}$ of sludge, attributed by the additional supply of external carbon source generated during the acidogenic fermentation.

\section{Methods}

Inoculum and feedstock

The inoculum for biogas production was taken from an anaerobic digester in a local wastewater treatment plant 
in Korea. The $\mathrm{pH}$, alkalinity, and volatile suspended solids (VSS) concentrations of the digester sludge were 7.5, $2.4 \mathrm{~g} \mathrm{CaCO}_{3} / \mathrm{L}$, and $5.6 \mathrm{~g} / \mathrm{L}$, respectively. Prior to $\mathrm{AD}$, it was shredded by a blender smaller than $1.0 \mathrm{~mm}$. The ES used was taken from the recycling pumping line of activated sludge process located at the same local wastewater treatment plant. The characteristics of ES were as follows: $\mathrm{pH} 7.0$, TCOD 24,000 mg/L, SCOD 590 $\mathrm{mg} / \mathrm{L}$, total solids (TS) $22,800 \mathrm{mg} / \mathrm{L}$, VS $18,000 \mathrm{mg} / \mathrm{L}$, total nitrogen (TN) $2200 \mathrm{mg} \mathrm{N} / \mathrm{L}$, ammonia $360 \mathrm{mg}$ $\mathrm{NH}_{4}-\mathrm{N} / \mathrm{L}$, and carbohydrate concentration $410 \mathrm{mg}$ Carbo. COD/L.

\section{Experiment}

In the alkali-pretreatment, $6 \mathrm{~N} \mathrm{KOH}$ solution was added to $0.5 \mathrm{~L}$ of ES sample to reach pH values of 10 and 11 . The samples were mixed for $0.5 \mathrm{~h}$ using a magnetic stirrer at $150 \mathrm{rpm}$ at $20^{\circ} \mathrm{C}$. In the thermal pretreatment, 0.5 $\mathrm{L}$ of ES was heated by using a water bath at $70^{\circ} \mathrm{C}$ and $90^{\circ} \mathrm{C}$ for $0.5 \mathrm{~h}$. To minimize evaporation during heating, the beaker was covered with aluminum foil.

The biogas production was conducted using the serum bottles having an effective volume of $100 \mathrm{~mL}$ (total volume of $250 \mathrm{~mL}$ ). The ES, inoculum, diluting water, and $1 \mathrm{~mL}$ of trace element solution made according to Kim et al. 2006 [40] were added to set a substrate concentration and inoculum to substrate ratio at $3.0 \mathrm{~g} \mathrm{COD} / \mathrm{L}$, and 2.0 (g VSS/g COD). After adjusting an initial $\mathrm{pH}$ to $7.5 \pm 0.1$ using $2 \mathrm{~N} \mathrm{KOH}$ and $2 \mathrm{~N} \mathrm{HCl}$ solutions, the serum bottles were purged with $\mathrm{N}_{2}$ gas for 5 min to establish an anaerobic condition. In case of acids generation for S3, pretreated ES was added to the serum bottle without $\mathrm{pH}$ adjustment for $7 \mathrm{~d}$ under anaerobic condition. No extra-inoculum and diluting water were added to obtain self-generated organic acids from ES. After acid fermentation, the broth was centrifuged at $6000 \mathrm{rpm}$ for $10 \mathrm{~min}$, and the solid residue was only further used for biogas production. All bottles were placed in a shaking incubator controlled at $35^{\circ} \mathrm{C}$ and $150 \mathrm{rpm}$. The tests were carried out in duplicate, and the results were averaged.

\section{Economic assessment}

The economic assessment was carried out for three different scenarios, considering the input cost and obtained values. Pretreatment (heat and chemical dose), and electricity cost for stirring, and heating during the fermentation were included in the input cost. The obtained values were calculated based on the amount of produced $\mathrm{CH}_{4}$, organic acids, and the reduction of sludge. The economic benefit from ES reduction $(0.28 \mathrm{USD} / \mathrm{kg} \mathrm{VS})$ was calculated using according to Kavitha et al. [22]. The energy needed for heating was calculated using the following Eq. (1) [41].

$$
\text { Energy (heat) } Q=\rho \times V \times C_{p} \times\left(T_{f}-T_{i}\right)
$$

, where $\mathrm{Q}$ is the heat energy needed to heat the sludge $(\mathrm{kJ}), \rho$ is the density of sludge $\left(\mathrm{kg} / \mathrm{m}^{3}\right), \mathrm{V}$ is the volume of sludge $\left(\mathrm{m}^{3}\right), \mathrm{C}_{\mathrm{p}}$ is specific heat of sludge $\left(\mathrm{kJ} / \mathrm{kg} .{ }^{\circ} \mathrm{C}\right)$ $\left(4.2 \mathrm{~kJ} / \mathrm{kg} \cdot{ }^{\circ} \mathrm{C}\right)$, and $\mathrm{T}_{\mathrm{i}}$ and $\mathrm{T}_{\mathrm{f}}$ are initial and final temperatures $\left({ }^{\circ} \mathrm{C}\right)$ of the sludge, respectively.

For the same economic criteria, all energy costs were calculated based on the commercial natural gas price of 0.014 USD/MJ [42]. The obtained value from the organic acids generation was calculated by considering the carbon source cost based on methanol.

\section{Analytical methods}

The concentrations of TS, VS, COD, TN, VSS, and ammonia were measured by standard methods [43]. The carbohydrate concentration was determined by the colorimetric method [44]. The produced biogas was adjusted to the standard conditions of temperature $\left(0{ }^{\circ} \mathrm{C}\right)$ and pressure $(760 \mathrm{mmHg})$ (STP). The $\mathrm{CH}_{4}$ and $\mathrm{CO}_{2}$ content in the biogas were measured by gas chromatography (GC, Gow Mac series 580) equipped with a 1.8 $\mathrm{m} \times 3.2 \mathrm{~mm}$ Porapak Q (80/100 mesh) column using $\mathrm{N}_{2}$ as a carrier gas. The temperatures of injector, detector, and column were kept at 80,90 , and $80^{\circ} \mathrm{C}$, respectively. Organic acids were analyzed by a high performance liquid chromatography (HPLC) (LC-10A model, SHIMADZU Co.) with an ultraviolet $(215 \mathrm{~nm})$ detector (UV1000, SHIMADZU) and a $100 \mathrm{~mm} \times 7.8 \mathrm{~mm}$ fast Acid Analysis column (HPX-87H, Bio-Rad Lab.) using $0.005 \mathrm{M} \mathrm{H}_{2} \mathrm{SO}_{4}$ as a mobile phase. The liquid samples were pretreated with a $0.20 \mu \mathrm{m}$ membrane filter before injection to HPLC. Biogas yield was calculated by comparing the actual production of $\mathrm{CH}_{4}$ produced to the theoretical maximum (350 $\left.\mathrm{mL} \mathrm{CH}_{4} / \mathrm{g} \mathrm{COD}\right)$ [5].

\section{Microbial community analysis}

To analyze the change in bacterial communities, the next generation sequencing (NGS) method was used. Samples were obtained for Deoxyribonucleic acids (DNAs) extraction after pretreatment. DNA in the samples was extracted and purified using an Ultraclean Soil DNA kit (Cat \#12800-50; Mo Bio Laboratories, lnc., USA) and an Ultra Clean Microbial DNA Isolation Kit (Mo Bio Laboratories, CA, USA). Then the preparation of libraries and the next procedure for emPCR was performed as previously described method [45]. The $16 \mathrm{~S}$ universal primers 27F (5'GAGTTTGATCMTGGC TCAG3') and 800R (5'TACCAGGGTATCTAATCC3') were used for amplifying the $16 \mathrm{~s}$ rRNA genes [46]. After the PCR reaction, products were purified using AMPure beads (Beckman coulter). Sequencing was then performed using a 454pyrosequencing Genome Sequencer FLX Titanium (Life Sciences,CT, USA), following the 
manufacturer's instructions, by a commercial sequencing facility (Macrogen, Seoul, Korea).

The sequencing data from the pyrosequencing were analyzed with the software MOTHUR for pre-processing (quality-adjustment, barcode split), identification of operational taxonomic units (OTUs), taxonomic assignment, community comparison, and statistical analysis. The methods for sequence filtration and trimming were done as previously described [46]. The sequences spanning the same region were then realigned with the NCBI BLAST database (www.ncbi.nlm.nih.gov).

\section{Abbreviations}

AD: Anaerobic digestion; COD: Chemical oxygen demand;

DNA: Deoxyribonucleic acid; ES: Excess sludge; GC: Gas chromatography; HPLC: High performance liquid chromatography; NGS: Next generation sequencing: OTU: Operational taxonomic unit; SCOD: Soluble chemical oxygen demand; STP: Standard conditions of temperature and pressure; TCOD: Total chemical oxygen demand; TN: Total nitrogen; TS: Total solids; VS: Volatile solids; VSS: Volatile suspended solids

\section{Acknowledgements}

Not applicable.

\section{Funding}

This work was supported by INHA UNIVERSITY Research Grant (INHA-5580001). The funding form comprised of financial support and providing facilities required for samples' analysis.

\section{Availability of data and materials}

Please contact the corresponding author for data requests.

\section{Authors' contributions}

$\mathrm{M}-\mathrm{KL}$ performed experiments of fermentation and wrote this part in the manuscript, while Y-MY contributed with the microbial analysis and its discussion writing. D-HK was responsible for making the experimental design and revising the whole manuscript. All authors have read and approved the final manuscript.

\section{Competing interests}

The authors declare that they have no competing interests.

\section{Publisher's Note}

Springer Nature remains neutral with regard to jurisdictional claims in published maps and institutional affiliations.

\section{Author details}

${ }^{1}$ Department of Civil Engineering, Inha University, 100 Inharo, Michuhol-gu, Incheon 22212, Republic of Korea. 'Department of Environmental Health, Daejeon Health Institute of Technology 21 Chungjeong-ro, Dong-gu, Daejeon 34504, Republic of Korea.

Received: 22 November 2018 Accepted: 8 April 2019

Published online: 16 May 2019

\section{References}

1. Wilson CA, Novak JT. Hydrolysis of macromolecular components of primary and secondary wastewater sludge by thermal hydrolytic pretreatment. Water Res. 2009:43:4489-98.

2. Cho SK, Ju HJ, Lee JG, Kim SH. Alkali-mechanical pretreatment process for enhanced anaerobic digestion of thickened waste activated sludge with a novel crushing device. Performance evaluation and economic analysis. Bioresour Technol. 2014;165:183-90.

3. Appels L, Degrève J, Van der Bruggen B, Van Impe J, Dewil R. Influence of low temperature thermal pre-treatment on sludge solubilisation, heavy metal release and anaerobic digestion. Bioresour Technol. 2010;101:5743-8.
4. Kuglarz M, Karakashev D, Angelidaki I. Microwave and thermal pretreatment as methods for increasing the biogas potential of secondary sludge from municipal wastewater treatment plants. Bioresour Technol. 2013;134:290-7.

5. Kim DH, Cho SK, Lee MK, Kim MS. Increased solubilization of excess sludge does not always result in enhanced anaerobic digestion efficiency. Bioresour Technol. 2013;143:660-4.

6. Lin JG, Ma YS, Huang CC. Alkaline hydrolysis of the sludge generated from a high-strength, nitrogenous-wastewater biological-treatment process. Bioresour Technol. 1998:65:35-42.

7. Hiraoka M, Takeda N, Sakai S, Yasuda A. Highly efficient anaerobic digestion with thermal pre-treatment. Water Sci Technol. 1985;17:529-39.

8. Neyens E, Baeyens J. A review of thermal sludge pre-treatment processes to improve dewaterability. J Hazard Mater. 2003:B98:51-67.

9. Kampas P, Parsons SA, Pearce P, Ledoux S, Vale P, Churchley J, Cartmell E. Mechanical sludge disintegration for the production of carbon source for biological nutrient removal. Water Res. 2007:41:1734-42.

10. Yang Q, Yi J, Luo K, Jing X, Li X, Liu Y, Zeng G. Improving disintegration and acidification of waste activated sludge by combined alkaline and microwave pretreatment. Process Saf Environ Prot. 2013:91:521-6.

11. Kondusamy D, Kalamdhad AS. Pre-treatment and anaerobic digestion of food waste for high rate methane production - a review. J Environ Chem Eng. 2014;2:1821-30

12. Park WJ, Ahn JH. Effects of microwave pretreatment on mesophilic anaerobic digestion for mixture of primary and secondary sludges compared with thermal pretreatment. Environ Eng Res. 2011;16:103-9.

13. Mirmasoumi S, Saray RK, Ebrahimi S. Evaluation of thermal pretreatment and digestion temperature rise in a biogas fueled combined cooling, heat, and power system using exergo-economic analysis. Energy Convers Manag. 2018:163:219-38.

14. Chen G, Wang X, Li J, Yan B, Wang Y, Wu X, Velichkova R, Cheng Z, Ma W. Environmental, energy, and economic analysis of integrated treatment of municipal solid waste and sewage sludge: a case study in China. Sci Total Environ. 2019;647:1433-43.

15. Ma H, Chen X, Liu H, Liu H, Fua B. Improved volatile fatty acids anaerobic production from waste activated sludge by $\mathrm{pH}$ regulation: alkali or neutral pH? Waste Manag. 2016:48:397-403.

16. Feng $L$, Chen $Y$, Zheng $X$. Enhancement of waste activated sludge protein conversion and volatile fatty acids accumulation during waste activated sludge anaerobic fermentation by carbohydrate substrate addition: the effect of pH. Environ Sci Technol. 2009:43:4373-80.

17. Grabinska-Loniewska A. Biocenosis diversity and denitrification efficiency. Water Res. 1991;25:1575-82.

18. Yuan H, Chen Y, Zhang H, Jiang S, Zhou Q, Gu G. Improved bioproduction of short-chain fatty acids(SCFAs) from excess sludge under alkali conditions. Environ Sci Technol. 2006:40:2025-9.

19. Xiao B, Liu J. Biological hydrogen production from sterilized sewage sludge by anaerobic self-fermentation. J Hazard Mater. 2009:168:163-7.

20. Zhang P, Chen YG, Zhou Q, Zheng X, Zhu XY, Zhao YX. Understanding short-chain fatty acids accumulation enhanced in waste activated sludge alkali fermentation: kinetics and microbiology. Environ Sci Technol. 2010;44: 9343-8.

21. Ueki A, Akasaka H, Suzuki D, Ueki K. Paludibacter propionicigenes gen. Nov., sp nov., a novel strictly anaerobic, gram-negative, propionate-producing bacterium isolated from plant residue in irrigated rice-field soil in Japan. Int J Syst Evol Microbiol. 2006:56:39-44.

22. Kavitha S, Rajesh Banu J, Subitha G, Ushani U, Yeom IT. Impact of thermochemo-sonic pretreatment in solubilizing waste activated sludge for biogas production: energetic analysis and economic assessment. Bioresour Technol. 2016;219:479-86.

23. Zhen G, Lu X, Li YY, Zhao Y. Combined electrical-alkali pretreatment to increase the anaerobic hydrolysis rate of waste activated sludge during anaerobic digestion. Appl Energ. 2014;12:93-102.

24. Haug RT, Stuckey JM, Gossett PL, McCarty PL. Effect of thermal pretreatment on digestibility and dewaterability of organic sludges. J Water Pollut Control Fed. 1978;50:73-85

25. Climent M, Ferrer I, Baeza MDM, Artola A, Vázquez F, Font X. Effects of thermal and mechanical pretreatments of secondary sludge on biogas production under thermophilic conditions. Chem Eng Journal. 2007;133: 335-42.

26. Levin DB, Pitt L, Love M. Biohydrogen production: prospects and limitations to practical application. Int J Hydrogen Energ. 2004;29:173-85. 
27. Liu Y, Li X, Yuan Y, Du M. Short chain fatty acids accumulation and microbial community succession during ultrasonic-pretreated sludge anaerobic fermentation process: effect of alkali adjustment. Int Biodeterior Biodegradation. 2014;94:128-33.

28. Jin B, Wang S, Xing L, Li B, Peng Y. Long term effect of alkali types on waste activated sludge hydrolytic acidification and microbial community at low temperature. Bioresour Technol. 2016;200:587-97.

29. Tan HQ, Li TT, Zhu C, Zhang XQ, Wu M, Zhu XF. Parabacteroides chartae sp. nov., an obligately anaerobic species from wastewater of a paper mill. Int J Syst Evol Microbiol. 2012;62(11):2613-7.

30. Alauzet C, Marchandin H, Courtin P. Multilocus analysis reveals diversity in the genus Tissierella: description of Tissierella carlieri sp. nov. in the new class Tissierellia classis nov. Syst Appl Microbiol. 2014;37:23-34.

31. Zhang K, Song L, Dong X. Proteiniclasticum ruminis gen. Nov., sp. nov., a strictly anaerobic proteolytic bacterium isolated from yak rumen. Int I Syst Evol Micr. 2010;60:2221-5.

32. Appels L, Baeyens J, Degrève J, Dewil R. Principles and potential of the anaerobic digestion of waste-activated sludge. Prog Energy Combus Sci. 2008;34(6):755-81.

33. Penaud V, Delgenes JP, Moletta R. Thermo-chemical pretreatment of a microbial biomass: influence of sodium hydroxide addition on solubilization and anaerobic biodegradability. Enzyme Microb Tech. 1999;25:258-63.

34. Rittmann BE, McCarty PL. Environmental biotechnology: principles and applications. 1st ed. New York: McGraw Hill Education; 2001.

35. KITA, Korea international trade association. Import and export data of potassium hydroxide. 2018. http://stat.kita.net/stat/kts/pum/ ItemlmpExpDetailPopup.screen?p_code=2815200000. Accessed 3 Mar 2018.

36. Kavitha S, Rajesh BJ, Vinoth KJ, Rajkumar M. Improving the biogas production performance of municipal waste activated sludge via disperser induced microwave disintegration. Bioresour Technol. 2016;217:21-7.

37. Barlindhaug J, Ødegaard H. Thermal hydrolysis for the production of carbon source for de-nitrification. Water Sci Technol. 1996;34:371-8.

38. Æsøy A, Ødegaard H, Bach K, Pujol R, Hamon M. Denitrification in a packed bed biofilm reactor (BIOFOR)-experiments with different carbon sources. Water Res. 1998:32:1463-70.

39. Lu J, Gavala HN, Skiadas IV, Mladenovska Z, Ahring BK. Improving anaerobic sewage sludge digestion by implementation of a hyperthermophilic prehydrolysis step. J Environ Manag. 2008;88:881-9.

40. Kim DH, Han SK, Kim SH, Shin HS. Effect of gas sparging on continuous fermentative hydrogen production. Int J Hydrogen Energ. 2006;31:2158-69.

41. Passos F, Ferrer I. Microalgae conversion to biogas: thermal pretreatment contribution on net energy production. Environ Sci Technol. 2014;48:7171-8.

42. Korea gas corporation (KOGAS). Information of natural gas, http://www. kogas.or.kr/. Accessed 3 Mar 2018.

43. Andrew DE, American Public Health Association, American Water Works Association, Water Environment Federation. Standard methods for the examination of Water and Wastewater, 21st ed, Washington, D.C: APHAAWWA-WEF; 2005.

44. Dubois M, Gilles KA, Hamilton JK, Rebers PA, Smith F. Colorimetric method for determination of sugars and related substances. Anal Chem. 1956;28:350-6.

45. Na JG, Lee MK, Yun YM, Moon CM, Kim MS, Kim DH. Microbial community analysis of anaerobic granules in phenol-degrading UASB by next generation sequencing. Biochem Eng J. 2016;112:241-8.

46. Nam YD, Lee SY, Lim SI. Microbial community analysis of Korean soybean pastes by next-generation sequencing. Int J Food Microbiol. 2012;155:36-42.

\section{Ready to submit your research? Choose BMC and benefit from}

- fast, convenient online submission

- thorough peer review by experienced researchers in your field

- rapid publication on acceptance

- support for research data, including large and complex data types

- gold Open Access which fosters wider collaboration and increased citations

- maximum visibility for your research: over $100 \mathrm{M}$ website views per year

At BMC, research is always in progress.

Learn more biomedcentral.com/submissions 